\title{
Academic Achievement and Gender Peer Effects on Social Comparisons and Self-Regulated Learning Behaviors in A Taiwanese EFL Context
}

\author{
Wan-Jeng Chang \\ Department of Applied English \\ Overseas Chinese University \\ Email: cwj [AT] ocu.edu.tw
}

\begin{abstract}
The main purpose of the present article is to estimate academic achievement and gender peer effects on social comparisons and self-regulated learning behaviors in a Taiwanese EFL context. The participating students were 50 non-English-major freshmen studying in Central Taiwan. Analyses of the data reveal the following findings. First, female students preferred or felt more comfortable making social comparisons with other female students, and they applied more self-regulated learning strategies. Second, male students had a stronger drive to make social comparisons, and they would prepare harder over time for the tests. Third, students with relatively low ability tended toward upward comparison and tended to give up or only study the easy parts.
\end{abstract}

Keywords-peer effects, social comparisons, self-regulated learning behaviors, English as a Foreign Language (EFL)

\section{INTRODUCTION}

The influences of peers have long been of interest to educators. Regardless of whether they are aware of it, students have an impact on the educational experiences of others. For example, peer effects are a significant determinant of performance (Celant, 2013). However, apart from affecting productivity (such as academic achievement), peer effects also involve a social dimension. That is, students tend to use their classmates as references in developing their academic self-concept (Marsh \& Hau, 2003). This action is associated with social comparison behaviors. In other words, academic self-concept is formed mostly through social comparison processes (Schwarzer \& Jerusalem, 1989; Zeidner \& Schleyer, 1998). After the academic self-concept is formed, it shapes the individual's choice of learning approaches (Rodriguez, 2009). Specifically, academic self-concept is a critical self-regulation component (Rodriguez, 2009). Thus, self-regulated learning in a social comparison framework is discussed in this paper.

Most researchers assume peer effects occur in higher education (Griffith \& Rask, 2014), and the pivot of various major issues facing higher education is related to peer effects (Zimmerman, 2003). However, most of the studies concerning peer effects in education have focused on elementary and secondary schools, and there have been significantly fewer studies performed in the setting of higher education (Zimmerman, 2003). This is one of the reasons this study was undertaken.

Cultural diversity and institutional differences are also likely to affect the intensity of peer effects (Carman \& Zhang, 2012). Most of the literature on school peer effects only considers schools in the United States (Carman \& Zhang, 2012). Furthermore, to date, little research has explored social comparisons and self-regulated learning in a non-Western context. This paper adds to a growing body of literature on theoretical and empirical analyses of peer effects on student performance in EFL (English as a Foreign Language) settings. The policy implications discussed here may be applicable to universities in Taiwan in general.

To emphasize the importance of peer effects, it is vital to highlight the features of social comparison and selfregulated learning behaviors. To date, it is still unknown how students from varying backgrounds (for instance, gender, major, or place of birth) perform social comparisons and self-regulated learning behaviors differently. In this study, two variables - gender and relative ability - are used to measure these behaviors to clarify whether social comparison and self-regulated learning behaviors among university students differ according to these variables. The purpose of the present article is to estimate academic achievement and gender peer effects on social comparisons and self-regulated learning behaviors in a Taiwanese EFL context. It also aims to address practical implications and avenues for future research.

In this respect, the following research questions will be answered in this study. First, what are the distinctions between EFL university students of different genders who exhibit social comparison behaviors? Second, what are the 
distinctions between EFL university students of different genders who exhibit self-regulated learning behaviors? Third, what are the distinctions between EFL university students with varying skill levels who exhibit social comparison behaviors? Fourth, what are the distinctions between EFL university students with varying skill levels who exhibit selfregulated learning behaviors?

The current study circumvents four problems that typically constrain the analysis of peer effects with field data. First, some studies permitted the self-selection of peers as experiment subjects, which potentially introduced multiple uncontrollable factors. By contrast, this study uses random pairs as experimental peer groups to eliminate potential bias. Second, when the research participants know each other well, their social comparison behaviors may be performed outside the class instead of being focused solely on the scope of the experimental setting. This study selected freshmen as research participants to reduce the potential for peer interaction beyond the scope of the experiment. Third, to avoid selfreporting bias, instead of using self-reported entries in the questionnaire, the participants' relative ability was measured objectively. Finally, the relative ability of the research participants was measured by both oral exams and oral practices with an automatic speech analysis system called MyET. This means the participants' relative skill levels were checked by two sources rather than by a single source.

Overall, this study makes three contributions. First, it adds to the developing literature on the theoretical and empirical analyses of peer effects in higher education as well as in EFL settings. Second, it offers a new approach - the use of random pairs - to estimate the influence of peers. Third, it suggests that two variables - gender and relative ability - can be used to measure social comparisons and self-regulated learning behaviors. The results of analyses can thus be used to develop theoretical models that describe the processes behind student behaviors, with empirical implications for peer effect specifications.

\section{LITERATURE REVIEW}

\subsection{Peer Effects}

The behavior of EFL learners with varying academic achievements, in particular, is one of the issues targeted by the present study. The achievement differences between students potentially result largely from their academic experiences (Gamoran \& Berends, 1987). These academic experiences could be related to variables such as students, teaching, and learning processes (Kesici \& Erdogan, 2010). Peer effects also constitute one of the key factors affecting learning behaviors.

An understanding of the nature and presentation of peer effects in education is crucial because peer influences bear vital implications for education policies, student admissions, ability tracking, classroom organization, school choice, and sources of school quality, among other things (Sund, 2009; Brunello, De Paola, \& Scoppa, 2010; Carman \& Zhang, 2012; Ficano, 2012).

The influences of peers are substantial (Summers \& Wolf, 1977), and peer experiences may play a role in achievement-related beliefs and academic skills (Gest, et al., 2008). For example, peer-assisted learning can improve children's social and self-concept outcomes (Ginsburg-Block, Rohrbeck, \& Fantuzzo, 2006). Peers also induce stronger motivation (Eisenkopf, 2010), provide distinctive patterns of reinforcement for attitudes and behaviors with regard to achievement, and present unique learning opportunities through peer tutoring (Gest et al., 2008). Although most prior studies are based on data from elementary and middle schools, these insights may still be applicable to higher education (Oosterbeek \& van Ewijk, 2014).

Peer effects on student performance occur before, during, and after interaction (Eisenkopf, 2010). However, this influence depends on the ability of the individual student and the relative ability of others (Burke \& Sass, 2013). Most studies discovered that abler peers have a significant and positive effect on others' performance (Sund, 2009; Griffith \& Rask, 2014; Kiss, 2013; Vardardottir, 2013; Foster \& Frijters, 2010). Students with varying academic abilities may demonstrate varying results in terms of peer effects. Thus, relative ability is one of the variables discussed in the current paper.

Another variable discussed is gender. Understanding how gender affects peer influence may uncover variations in student performance across diverse fields or changes in academic behaviors over time. Therefore, recognizing the pattern of associated changes is essential (Oosterbeek \& van Ewijk, 2014). Several studies have discussed the issue of gender peer effects. For example, Griffith and Rask (2014) reported that male students are much more aware of peer ability than female students are. Another example is Ficano (2012), who proposed that male peers have a positive and statistically significant effect on other males, but no significant male or female peer influence exists on female students. Therefore, gender does play a role in peer effect.

Dijkstra et al. (2008) noted that the classroom environment and peers are important determinants of the academic self-concept. Marsh and Hau (2003) stated that students tend to use their classmates as a reference when developing their academic self-concept. As such, peer effects and academic self-concept appear to be related. In understanding peer effects, it is essential to recognize how academic self-concept works. 


\subsection{Academic Self-Concept}

Academic self-concept refers to an individual's perception of their ability in a particular academic area (Preckel, Niepel, Schneider, \& Brunner, 2013; Van Soom \& Donche, 2014). This subjective judgment considers the student's competence, interest in, and enjoyment of the subject in school (Ireson \& Hallam, 2009), and it is formed through the student's experience and interpretation of the learning environment (Guay, Ratelle, Roy, \& Litalien, 2010; Erten \& Burden, 2014). In the process of forming an academic self-concept, students must juxtapose their perceived accomplishments with appropriate references to evaluate their accomplishments (Marsh, Kuyper, Morin, Parker, \& Seaton, 2014). Students tend to use their classmates as references when evaluating their own accomplishments (Marsh and Hau, 2003).

Educational policy statements generally stress the importance of cultivating and maintaining a positive self-concept (Zeidner \& Schleyer, 1998). A positive academic self-concept is a critical outcome variable in itself and has beneficial effects on a broad range of desirable academic outcomes, directly or indirectly (Marsh \& Martin, 2011; Wouters, Germeijs, Colpin, \& Verschueren, 2011; Preckel, Niepel, Schneider, \& Brunner, 2013). In fact, a positive academic selfconcept is a highly agreeable goal as well as a means of facilitating subsequent educational choice behaviors, academic accomplishments, and academic achievement (Marsh, Kuyper, Morin, Parker, \& Seaton, 2014). Students with a strongly positive academic self-concept perform better in terms of academic achievement, effort, persistence, intrinsic motivation, and general psychosocial well-being (Wouters, Colpin, Van Damme, De Laet, \& Verschueren, 2013).

Academic self-concept and academic achievement are positively associated with and influence each other (Erten \& Burden, 2014; Van Soom \& Donche, 2014). Academic self-concept and student achievement are directly, even causally, linked (Van Soom \& Donche, 2014), and they are mutually reinforcing (Prince \& Nurius, 2014). According to the selfenhancement model, academic self-concept is a primary determinant of academic achievement, whereas the skill development model implies that academic self-concept emerges primarily as a consequence of academic achievement (Marsh, Byrne, \& Yeung, 1999). This means academic self-concept is both a cause and an effect of academic achievement (Marsh et al, 2005). Prince and Nurius (2014) pointed out that as students experience success, the academic self-concept is enhanced; as the academic self-concept is enhanced, drive, motivation, and academic accomplishments strengthen.

In addition to being associated with peer effects, gender has also been linked with academic self-concept. For example, Arefi, Naghibzadeh, and Boloki (2014) indicated that gender differences exist in academic self-concept. Marsh et al. (2005) also mentioned that academic self-concepts linked with gender differences are found in specific domains, such as English and mathematics.

Only a few studies discuss the relationship between language learning and academic self-concept (Erten \& Burden, 2014). One of these studies is related to the current paper. Marsh, Hau, and Kong (2002) found that prior positive academic self-concept in a six-year longitudinal sample of Hong Kong students had a positive impact on their language achievement. Marsh, Hau, and Kong's work demonstrates the value of academic self-concept in EFL settings.

Academic self-concept is an organized set of beliefs (Rodriguez, 2009). According to Rodriguez (2009), these beliefs are based on self-comparisons, social comparisons, dominance processes, and regulations of behavior. Reference group effect, or social comparison, bears the greatest influence over academic self-concept (Preckel, Niepel, Schneider, \& Brunner, 2013). It is believed that academic self-concept is largely shaped through the process of social comparison (Preckel, Zeidner, Goetz, \& Schleyer, 2008; Ireson \& Hallam, 2009).

\subsection{Social Comparison Theory}

The social comparison theory was proposed by Festinger in 1954. It argues that individuals have a fundamental desire to evaluate their abilities and opinions and strive to have stable, accurate evaluations of themselves (Dijkstra et al., 2008). This theory has created a practical social and psychological framework for understanding peer effects (Suls \& Wheeler, 2000). According to Sung, Huang, Tseng, and Chang (2014), social comparison may influence students in both the affective and cognitive domains. The affective domain involves motivation in learning, self-esteem, self-efficacy, and self-concept, whereas the cognitive domain is related to students' subsequent academic achievement.

Individuals typically compare themselves with others in the reference group who exhibit some similarity on aspects they consider to be personally relevant within the framework of a given subject area (Preckel, Zeidner, Goetz, \& Schleyer, 2008). According to Tholander (2011), students perform social comparisons to establish, protect, or recapture an image of success. It is difficult to avoid comparing oneself with others in a classroom setting; a classroom provides an extensive source of social comparisons because of its reward system, which is based on academic performance, perceived teacher concern with achievement, and parental pressure to perform well (Dijkstra et al., 2008).

Relative ability is also a crucial component of the social comparison framework. According to Felicio and Miller (1994), similarity is a vital determinant of comparison choice. When the abilities of others are considerably superior or inferior to those of an individual, it is not possible to precisely evaluate self ability (Dijkstra et al., 2008). Individuals 
tend to feel inspired by those who succeed (Bui \& Pelham, 1999). Thus, instead of downward comparisons, most individuals compare their abilities with those of others who perform slightly better than they do (Dijkstra et al., 2008). When considering an upward comparison target, the individual hopes to receive a good grade similar to that of the target in the future (Buunk, Kuyper, \& Van der Zee, 2005).

Some studies focus on gender effects in terms of social comparisons in academic environments, and the results typically reveal some significant behavioral differences between male and female subjects. For example, in the work of Buunk, Kuyper, and Van der Zee (2005), the researchers found that female students demonstrate more altruistic and empathic responses than male students, whereas male students present more egocentric and hostile responses to social comparison. Felicio and Miller (1994) revealed that female students compare themselves to male and female targets, whereas male students tend to compare themselves to male targets.

After students compare themselves with others, it is critical to analyze their subsequent behaviors. The subsequent behaviors discussed in this paper are students' self-regulated learning behaviors.

\subsection{Self-Regulated Learning}

Foster and Frijters (2010) indicated that the combination of peer quality, peer effort, and the individual's own effort is the crucial factor in educational production. Dijkstra et al. (2008) proposed that self-evaluation, self-enhancement, and self-improvement are three motives for social comparison. Felicio and Miller (1994) also stated that self-improvement and self-evaluative goals play significant roles in the comparison process. To sum up, the current paper argues that effort, self-enhancement, and self-improvement are the best responses for an individual in reacting and adjusting to a situation in the process of comparing themselves to their peers, or after that process of comparison. The current paper also proposes that self-regulated learning is an effective option for measuring effort, self-enhancement, and self-improvement.

According to Banarjee and Kumar (2014), self-regulated learning has several features of note. First, it is one of the critical predictors of student achievement and motivation. Second, self-regulation is significant to the learning process by which learners conduct their acquisition of knowledge. Third, self-regulated learning offers learners the chance to direct their own resources and improve their performance in the learning process. Fourth, self-regulated students take responsibility for their own learning processes and adopt various strategies to control and regulate their own learning and finally meet their academic goals.

Several studies pointed out that self-regulated students perform better on academic tests and measures of achievement (Schunk \& Zimmerman, 2007; Zimmerman, 2008; Zumbrunn, Tadlock, \& Roberts, 2011). Thus, high achievers may perform more self-regulated learning behaviors than underachievers.

Some studies found statistically significant variations among self-regulated learning variables with respect to gender (Yukselturk \& Bulut, 2009). For example, Bidjerano (2005) examined gender differences in the use of self-regulated learning strategies. The results revealed that female students surpassed male students in their ability to use self-regulated learning strategies such as rehearsal, organization, metacognition, time management skills, elaboration, and effort, but no statistically significant gender differences were apparent with respect to strategies such as studying with peers, seeking help, and using critical thinking skills. In another study by Zimermann and Martinez-Pons (1990), the findings revealed that the girls reported greater use of self-regulated learning strategies than the boys did, such as record keeping and monitoring, environmental structuring, and goal-setting and planning.

\subsection{MyET}

Technology is one example of a self-regulated learning strategy. My English Tutor (MyET), which was applied in this study, is an oral English e-learning platform. It offers desirable features of technology-enhanced language learning, such as convenience, opportunity for repeated practice, and hope for improvement and growth. MyET uses the Automatic Speech Analysis System, which can analyze learners' English speech and give them detailed information on their pronunciation, pitch, timing, emphasis, and scores, as well as specific feedback on how to improve (MyET, 2017). Some previous studies adopted MyET as their research tool (e.g., Chen, 2011; Lu \& Jaw, 2010; Hsieh, Dong, \& Wang, 2013). Hsieh, Dong, and Wang (2013) pointed out that MyET holds a large market share in Taiwan, with numerous colleges and senior high schools subscribing to it to enhance their English education programs. Furthermore, Lu and Jaw (2010) found that nearly $80 \%$ of their survey participants strongly agreed or agreed with the claim that the use of MyET could help them improve their English speaking skills. In the current study, MyET not only serves as a self-regulated learning strategy but also as a tool to verify the measurement of relative ability.

\section{METHODOLOGY}

This study utilizes an EFL setting in a conversational English class. The classes provide stronger frames of reference than the school because students are placed into classes according to their ability and they remain in those classes for most subjects (Wong \& Watkins, 2001; Ireson \& Hallam, 2009). Felicio and Miller (1994) stated that the convenience of 
comparison with others is a significant determinant of comparison selection. According to Dijkstra et al. (2008), most studies examining social comparison in the classroom have manipulated or established the comparison dimension, and the investigation usually involves performance on a certain test, exam, task, or school subject, or involves school achievement in general. The current study also follows these designs and uses oral tests to examine social comparisons and self-regulated learning behaviors.

The participating students were non-English-major freshmen studying in Central Taiwan. These students passed the entrance exam, with little difference between their abilities. Their English proficiency level was around the Common European Framework of Reference descriptors of A2. In other words, a similar comparison situation was created. The experiment period was a single semester of 18 weeks and covered one learning process. The students faced particular tasks; they could improve their performance on these tasks over time. Vardardottir (2013) suggested that studies that fail to identify peers are potentially missing out on information on the students' actual reference group. Thus, in this paper, the participants are first tested with a randomly assigned partner (pair treatment), and they each remain with their partner for the rest of the process.

Peer interaction can influence learning processes in several ways. For instance, peers may explain the task to each other (instructional argument). When the participants are assigned to pairs and tasked with taking oral tests, they hold certain beliefs about each other and about peer effects. Even if these beliefs are inaccurate, such beliefs may be even more vital to behavior than the truth (Foster \& Frijters, 2010).

It is challenging to estimate peer effects because of confounding effects that are likely to influence the results (Sund, 2009). The current paper avoids this bias by the following methods. First, to avoid the common teacher effect, the same teacher delivers the test throughout the experiment, and this teacher did not teach, tutor, or comment during each test. Second, to overcome difficulties that have hindered the separation of peer effects from omitted individual factors due to self-selection, the pairs were randomly assigned by the teacher. In this way, this experiment controlled for student fixed effects and teacher fixed effects simultaneously. These controls sharply limited the scope for bias from endogenous selection of peers and permitted a sharper estimate of the influence of classroom peers' ability. Third, skill level was measured through six oral English tests as well as six MyET scores to avoid single-source bias. The average scores of the oral tests matched the average MyET scores.

In each pair, one student had a higher level of skill than the other did. Of the 54 students who had originally joined the experiment, only 50 completed the questionnaires at the end of the semester. The study had 12 male participants and 38 female participants, and 26 participants had higher ability than the other 24 participants did.

The independent variables of this paper are gender and relative ability. The dependent variables are social comparison and self-regulated learning. The control factor is the learning environment of the participants, where they all have the same major, course instructor, learning materials, tests, and exams. The research tools include a social comparison questionnaire, a self-regulated learning questionnaire, MyET scores, and the oral test scores assessed by the instructor. The questionnaires are designed by the author.

\section{RESULTS AND DISCUSSION}

\subsection{Research Question 1: What are the Distinctions between EFL University Students of Different Genders who Exhibit Social Comparison Behaviors?}

Tables 1 and 2 present the means, standard deviations, and independent samples test of the key variable gender with regard to statistically significant social comparison behaviors. Results indicate that (1) more female than male students preferred to have partners of the same gender, and (2) male students wanted to know the scores of their partners more than the female students did.

Table 1: T-test for Gender in terms of Social Comparison Behaviors

(Group Statistics)

\begin{tabular}{lllcc}
\hline \hline & Gender & Mean & Std. Deviation & $\begin{array}{c}\text { Std. Error } \\
\text { Mean }\end{array}$ \\
\hline $\begin{array}{l}\text { I hope that my test partner } \\
\text { is the same gender as I am }\end{array}$ & Male & 2.75 & 0.62 & 0.18 \\
\hline I want to know the score of & Female & 3.11 & 0.45 & $7.34 \mathrm{E}-02$ \\
my test partner & Male & 3.58 & 0.90 & 0.26 \\
& Female & 3.05 & 0.73 & 0.12
\end{tabular}


Table 2: T-test for Gender in terms of Social Comparison Behaviors

(Independent Samples Test)

\begin{tabular}{|c|c|c|c|c|c|c|c|c|c|c|}
\hline & & \multicolumn{2}{|c|}{$\begin{array}{c}\text { Levene's Test } \\
\text { for Equality } \\
\text { of Variances }\end{array}$} & \multicolumn{7}{|c|}{$t$-test for Equality of Means } \\
\hline & & \multirow[t]{2}{*}{$\mathrm{F}$} & \multirow[t]{2}{*}{ Sig. } & \multirow[t]{2}{*}{$t$} & \multirow[t]{2}{*}{$\mathrm{df}$} & \multirow[t]{2}{*}{$\begin{array}{c}\text { Sig. } \\
\text { (2-tailed) }\end{array}$} & \multirow[t]{2}{*}{$\begin{array}{c}\text { Mean } \\
\text { Difference }\end{array}$} & \multirow[t]{2}{*}{$\begin{array}{l}\text { Std. Error } \\
\text { Difference }\end{array}$} & \multicolumn{2}{|c|}{$\begin{array}{l}\text { 95\% Confidence } \\
\text { Interval of the } \\
\text { Difference }\end{array}$} \\
\hline & & & & & & & & & Lower & Upper \\
\hline \multirow{2}{*}{$\begin{array}{l}\text { I hope that my } \\
\text { test partner is the } \\
\text { same gender } \\
\text { as I am }\end{array}$} & $\begin{array}{c}\text { Equal Variances } \\
\text { Assumed }\end{array}$ & 1.792 & 0.187 & -2.161 & 48 & 0.036 & -0.36 & 0.16 & -0.69 & $-2.48 \mathrm{E}-02$ \\
\hline & $\begin{array}{c}\text { Equal Variances } \\
\text { Not Assumed }\end{array}$ & & & -1.832 & 14.868 & 0.087 & -0.36 & 0.19 & -0.77 & $5.83 \mathrm{E}-02$ \\
\hline \multirow{2}{*}{$\begin{array}{l}\text { I want to know } \\
\text { the score of } \\
\text { my test partner }\end{array}$} & $\begin{array}{c}\text { Equal Variances } \\
\text { Assumed }\end{array}$ & 2.725 & 0.105 & 2.069 & 48 & 0.044 & 0.53 & 0.26 & $1.49 \mathrm{E}-02$ & 1.05 \\
\hline & $\begin{array}{c}\text { Equal Variances } \\
\text { Not Assumed }\end{array}$ & & & 1.857 & 15.884 & 0.082 & 0.53 & 0.29 & $-7.56 \mathrm{E}-02$ & 1.14 \\
\hline
\end{tabular}

$$
\mathrm{p}<.05
$$

\subsection{Research Question 2: What are the Distinctions between EFL University Students of Different Genders who Exhibit Self-Regulated Learning Behaviors?}

Tables 3 and 4 present the means, standard deviations, and independent samples test of the key variable gender with regard to statistically significant self-regulated learning behaviors. The results indicate that (1) more male than female students prepared for the oral tests by studying harder over time, (2) female students applied reciting strategies more than the male students did, and (3) more female than male students tended to consult the dictionary.

Table 3: T-test for Gender in terms of Self-Regulated Learning Behaviors

(Group Statistics)

\begin{tabular}{lllcc}
\hline \hline & Gender & Mean & Std. Deviation & $\begin{array}{c}\text { Std. Error } \\
\text { Mean }\end{array}$ \\
\hline $\begin{array}{l}\text { I study harder and harder to } \\
\text { prepare for the oral tests }\end{array}$ & Male & 3.17 & 0.58 & 0.17 \\
\hline When I prepare for the oral tests, & Female & 2.74 & 0.60 & $9.75 \mathrm{E}-02$ \\
$\begin{array}{l}\text { I apply reciting strategies } \\
\text { When I prepare for the oral tests, }\end{array}$ & Male & 2.83 & 0.72 & 0.21 \\
$\begin{array}{l}\text { I usually consult a dictionary and } \\
\text { confirm the vocabulary }\end{array}$ & Male & 3.47 & 0.73 & 0.12 \\
\hline
\end{tabular}


Table 4: T-test for Gender in terms of Self-Regulated Learning Behaviors

(Independent Samples Test)

\begin{tabular}{|c|c|c|c|c|c|c|c|c|c|c|}
\hline & & \multicolumn{2}{|c|}{$\begin{array}{c}\text { Levene's Test } \\
\text { for Equality } \\
\text { of Variances }\end{array}$} & \multicolumn{7}{|c|}{$t$-test for Equality of Means } \\
\hline & & \multirow[t]{2}{*}{$\mathrm{F}$} & \multirow[t]{2}{*}{ Sig. } & \multirow[t]{2}{*}{$t$} & \multirow[t]{2}{*}{ df } & \multirow[t]{2}{*}{$\begin{array}{c}\text { Sig. } \\
\text { (2-tailed) }\end{array}$} & \multirow[t]{2}{*}{$\begin{array}{c}\text { Mean } \\
\text { Difference }\end{array}$} & \multirow[t]{2}{*}{$\begin{array}{l}\text { Std. Error } \\
\text { Difference }\end{array}$} & \multicolumn{2}{|c|}{$\begin{array}{l}95 \% \text { Confidence } \\
\text { Interval of the } \\
\text { Difference }\end{array}$} \\
\hline & & & & & & & & & Lower & Upper \\
\hline $\begin{array}{l}\text { I study harder } \\
\text { and harder to }\end{array}$ & $\begin{array}{c}\text { Equal Variances } \\
\text { Assumed }\end{array}$ & 0.275 & 0.602 & 2.179 & 48 & 0.034 & 0.43 & 0.20 & $3.32 \mathrm{E}-02$ & 0.83 \\
\hline $\begin{array}{l}\text { prepare for the } \\
\text { oral tests }\end{array}$ & $\begin{array}{c}\text { Equal Variances } \\
\text { Not Assumed }\end{array}$ & & & 2.226 & 19.152 & 0.038 & 0.43 & 0.19 & 2.59E-02 & 0.83 \\
\hline $\begin{array}{l}\text { When I prepare } \\
\text { for the oral tests, }\end{array}$ & $\begin{array}{c}\text { Equal Variances } \\
\text { Assumed }\end{array}$ & 1.311 & 0.258 & -2.672 & 48 & 0.010 & -0.64 & 0.24 & -1.12 & -0.16 \\
\hline $\begin{array}{l}\text { I apply } \\
\text { reciting strategies }\end{array}$ & $\begin{array}{c}\text { Equal Variances } \\
\text { Not Assumed }\end{array}$ & & & -2.687 & 18.665 & 0.015 & -0.64 & 0.24 & -1.14 & -0.14 \\
\hline $\begin{array}{l}\text { I usually check } \\
\text { a dictionary and }\end{array}$ & $\begin{array}{c}\text { Equal Variances } \\
\text { Assumed }\end{array}$ & 2.651 & 0.110 & -2.304 & 48 & 0.026 & -0.62 & 0.27 & -1.17 & $-7.93 \mathrm{E}-02$ \\
\hline $\begin{array}{l}\text { confirm the } \\
\text { vocabulary }\end{array}$ & $\begin{array}{c}\text { Equal Variances } \\
\text { Not Assumed }\end{array}$ & & & -2.086 & 16.061 & 0.053 & -0.62 & 0.30 & -1.26 & $9.80 \mathrm{E}-03$ \\
\hline
\end{tabular}

\subsection{Research Question 3: What are the Distinctions between EFL University Students with Varying Skill Levels in terms of Social Comparison Behaviors?}

Tables 5 and 6 present the means, standard deviations, and independent samples test of the key variable relative ability with regard to statistically significant social comparison behaviors. The results indicate that the students with relatively low ability wanted partners with better ability. That is, the students with relatively low ability tended toward upward comparison.

(Group Statistics)

Table 5: T-test for Relative Ability in terms of Social Comparison Behaviors

\begin{tabular}{lcccc}
\hline \hline & Level & Mean & Std. Deviation & $\begin{array}{c}\text { Std. Error } \\
\text { Mean }\end{array}$ \\
\hline I hope the English ability of my & Higher & 3.19 & 0.40 & $7.88 \mathrm{E}-02$ \\
test partner is better than mine & Lower & 3.92 & 0.88 & 0.18 \\
\hline
\end{tabular}

Table 6: T-test for Relative Ability in terms of Social Comparison Behaviors (Independent Samples Test)

\begin{tabular}{|c|c|c|c|c|c|c|c|c|c|c|}
\hline & & \multicolumn{2}{|c|}{$\begin{array}{c}\text { Levene's Test } \\
\text { for Equality } \\
\text { of Variances }\end{array}$} & \multicolumn{7}{|c|}{$t$-test for Equality of Means } \\
\hline & & $\mathrm{F}$ & Sig. & \multirow[t]{2}{*}{$t$} & \multirow[t]{2}{*}{$\mathrm{df}$} & \multirow[t]{2}{*}{$\begin{array}{c}\text { Sig. } \\
\text { (2-tailed) }\end{array}$} & \multirow[t]{2}{*}{$\begin{array}{c}\text { Mean } \\
\text { Difference }\end{array}$} & \multirow[t]{2}{*}{$\begin{array}{l}\text { Std. Error } \\
\text { Difference }\end{array}$} & \multicolumn{2}{|c|}{$\begin{array}{l}95 \% \text { Confidence } \\
\text { Interval of the } \\
\text { Difference }\end{array}$} \\
\hline & & & & & & & & & Lower & Upper \\
\hline $\begin{array}{l}\text { I hope the } \\
\text { English ability }\end{array}$ & $\begin{array}{c}\text { Equal Variances } \\
\text { Assumed }\end{array}$ & 22.967 & 0.000 & -3.791 & 48 & 0.000 & -0.72 & 0.19 & -1.11 & -0.34 \\
\hline $\begin{array}{l}\text { of my test partner } \\
\text { is better than mine }\end{array}$ & $\begin{array}{c}\text { Equal Variances } \\
\text { Not Assumed }\end{array}$ & & & -3.691 & 31.621 & 0.001 & -0.72 & 0.20 & -1.12 & -0.32 \\
\hline
\end{tabular}
$\mathrm{p}<.05$

\subsection{Research Question 4: What are the Distinctions between EFL University Students with Varying Skill Levels in terms of Self-Regulated Learning Behaviors?}

Tables 7 and 8 present the means, standard deviations, and independent samples test of the key variable relative ability with regard to statistically significant self-regulated learning behaviors. The results indicate that the students with relatively low ability tended to give up or only studied the easy parts. 
(Group Statistics)

Table 7: T-test for Relative Ability in terms of Self-Regulated Learning Behaviors

\begin{tabular}{lcccc}
\hline \hline & Level & Mean & Std. Deviation & $\begin{array}{c}\text { Std. Error } \\
\text { Mean }\end{array}$ \\
\hline $\begin{array}{l}\text { When the test is difficult, I } \\
\text { usually give up or I only }\end{array}$ Higher & 2.35 & 0.89 & 0.17 \\
study the easy parts & Lower & 3.08 & 0.93 & 0.19 \\
\hline
\end{tabular}

Table 8: T-test for Relative Ability in terms of Self-Regulated Learning Behaviors

(Independent Samples Test)

\begin{tabular}{|c|c|c|c|c|c|c|c|c|c|c|}
\hline & & \multicolumn{2}{|c|}{$\begin{array}{c}\text { Levene's Test } \\
\text { for Equality } \\
\text { of Variances }\end{array}$} & \multicolumn{5}{|c|}{$t$-test for Equality of Means } & & \\
\hline & & $\mathrm{F}$ & Sig. & $t$ & $\mathrm{df}$ & $\begin{array}{c}\text { Sig. } \\
\text { (2-tailed) }\end{array}$ & $\begin{array}{c}\text { Mean } \\
\text { Difference }\end{array}$ & $\begin{array}{l}\text { Std. Error } \\
\text { Difference }\end{array}$ & \multicolumn{2}{|c|}{$\begin{array}{l}\text { 95\% Confidenc } \\
\text { Interval of the } \\
\text { Difference }\end{array}$} \\
\hline & & & & & & & & & Lower & Upper \\
\hline $\begin{array}{l}\text { When the test is } \\
\text { difficult, I usually }\end{array}$ & $\begin{array}{c}\text { Equal Variances } \\
\text { Assumed }\end{array}$ & 0.145 & 0.705 & -2.863 & 48 & 0.006 & -0.74 & 0.26 & -1.25 & -0.22 \\
\hline $\begin{array}{l}\text { give up or I only } \\
\text { study the easy parts }\end{array}$ & $\begin{array}{c}\text { Equal Variances } \\
\text { Not Assumed }\end{array}$ & & & -2.858 & $\$ 7.296$ & 0.006 & -0.74 & 0.26 & -1.26 & -0.22 \\
\hline
\end{tabular}

\section{CONCLUSION}

This study placed students within classroom groups with a specific teacher and observed the group of students. Numerous other studies have focused on either social comparisons or self-regulated learning. Although it is not the first to do so, this paper adds further value by adopting both of these variables simultaneously, focusing on EFL settings in particular. This is the first study to control peer effects in pairs. Analyses of the data reveal the following findings. First, female students preferred or felt more comfortable making social comparisons with other female students, and they applied more self-regulated learning strategies, such as reciting strategies and consulting a dictionary, than male students did. These initial findings do not match those of Felicio and Miller (1994), who proposed that female students compare themselves to both male and female targets, whereas male students tend to compare themselves solely to male targets. The second part of the current study's findings agree with the work of Bidjerano (2005) and Zimermann and MartinezPons (1990), who noted that female students make greater use of self-regulated learning strategies than male students do. Second, male students had a stronger drive to make social comparisons, and they would prepare harder over time for the tests. This result is similar to that of Griffith and Rask (2014), who reported that male students are much more aware of their peers' ability than female students are. This finding is also consistent with Buunk, Kuyper, and Van der Zee (2005), who found the male students were more egocentric and presented hostile responses to social comparisons. Third, students with relatively low ability tended toward upward comparison and tended to give up or only study the easy parts. According to Buunk, Kuyper, and Van der Zee (2005), with an upward comparison target, the individual hopes to receive a good grade similar to that of the target in the future. Students with relatively low ability tended toward upward comparison, potentially for the purpose of self-improvement. As for those who gave up easily or only studied the easy parts, this may be one of the reasons why some of them remained at relatively low levels of ability. Nevertheless, further evidence is certainly required to confirm these conclusions.

Some limitations of the study need to be addressed. First, the participating students were 50 non-English-major freshmen studying in Central Taiwan. Future researchers could administer the survey in diverse regions and expand the number of schools and participating students. Second, the current paper uses questionnaires as a research tool. Other research methods should be considered as well. Additional qualitative research to explain the outcomes is especially recommended. Third, the experiment was performed over a single semester. Future studies can expand the duration of the experiment. Fourth, this paper only focuses on one conversational English class. Other types of courses could be used, or the number of classes could be increased. Fifth, the independent variables of this paper are gender and relative ability, and the dependent variables are social comparison and self-regulated learning. Future studies can broaden the scope of the research and include other variables.

\section{REFERENCES}

[1] Arefi, M., Naghibzadeh, M., \& Boloki, A. (2014). The relationship of parental attachment, peer attachment, and academic self-concept to academic achievement of high school students. International Journal of Academic Research, 6(5), 73-78. 
[2] Banarjee, P., \& Kumar, K. (2014). A Study on Self-Regulated Learning and Academic Achievement among the Science Graduate Students. International Journal of Multidisciplinary Approach \& Studies, 1(6), 329-342.

[3] Bidjerano, T. (2005). Gender differences in self-regulated learning. Paper presented at the Annual Meeting of the Northeastern Educational Research Association, October 19-21, Kerhonkson, NY, USA.

[4] Brunello, G., De Paola, M., \& Scoppa, V. (2010). Peer effects in higher education: Does the field of study matter?. Economic Inquiry, 48(3), 621-634.

[5] Bui, K. V. T., \& Pelham, B. W. (1999). Cognitive and affective reactions to social comparison. Journal of Social Behavior and Personality, 14, 569-583.

[6] Burke, M. A., \& Sass, T. R. (2013). Classroom peer effects and student achievement. Journal of Labor Economics, 31(1), 51-82.

[7] Buunk, B. P., Kuyper, H., \& Van der Zee, Y. G. (2005). Affective response to social comparison in the classroom. Basic and applied social psychology, 27(3), 229-237.

[8] Carman, K. G., \& Zhang, L. (2012). Classroom peer effects and academic achievement: Evidence from a Chinese middle school. China Economic Review, 23(2), 223-237.

[9] Celant, S. (2013). The analysis of students' academic achievement: the evaluation of peer effects through relational links. Quality \& Quantity, 47(2), 615-631.

[10] Chen, H. H. J. (2011). Developing and evaluating an oral skills training website supported by automatic speech recognition technology. ReCALL, 23(01), 59-78.

[11] Dijkstra, P., Kuyper, H., van der Werf, G., Buunk, A. P., \& van der Zee, Y. G. (2008). Social comparison in the classroom: A review. Review of Educational Research, 78(4), 828-879.

[12] Eisenkopf, G. (2010). Peer effects, motivation, and learning. Economics of Education Review, 29(3), 364-374.

[13] Erten, İ. H., \& Burden, R. L. (2014). The relationship between academic self-concept, attributions, and L2 achievement. System, 42, 391-401.

[14]Felicio, D. M., \& Miller, C. T. (1994). Social comparison in medical school: What students say about gender and similarity. Basic and applied social psychology, 15(3), 277-296.

[15] Ficano, C. C. (2012). Peer effects in college academic outcomes - Gender matters! Economics of Education Review, 31(6), 1102-1115.

[16] Foster, G., \& Frijters, P. (2010). Students' beliefs about peer effects. Economics Letters, 108(3), $260-263$.

[17] Gamoran, A., \& Berends, M. (1987). The effects of stratification in secondary schools: Synthesis of survey and ethnographic research. Review of educational research, 57(4), 415-435.

[18] Gest, S. D., Rulison, K. L., Davidson, A. J., \& Welsh, J. A. (2008). A reputation for success (or failure): the association of peer academic reputations with academic self-concept, effort, and performance across the upper elementary grades. Developmental psychology, 44(3), 625.

[19] Ginsburg-Block, M. D., Rohrbeck, C. A., \& Fantuzzo, J. W. (2006). A meta-analytic review of social, self-concept, and behavioral outcomes of peer-assisted learning. Journal of Educational Psychology, 98(4), 732-749.

[20] Griffith, A. L., \& Rask, K. N. (2014). Peer effects in higher education: A look at heterogeneous impacts. Economics of Education Review, 39, 65-77.

[21] Guay, F., Ratelle, C. F., Roy, A., \& Litalien, D. (2010). Academic self-concept, autonomous academic motivation, and academic achievement: Mediating and additive effects. Learning \& Individual Differences, 20(6), 644-653.

[22] Hsieh, K. T., Dong, D. H., \& Wang, L. Y. (2013). A preliminary study of applying shadowing technique to English intonation instruction. Taiwan Journal of Linguistics, 11(2), 43-65.

[23] Ireson, J., \& Hallam, S. (2009). Academic self-concepts in adolescence: Relations with achievement and ability grouping in schools. Learning and Instruction, 19(3), 201-213.

[24] Kesici, S., \& Erdogan, A. (2010). Mathematics anxiety according to middle school students' achievement motivation and social comparison. Education, 131(1), 54-63.

[25] Kiss, D. (2013). The impact of peer achievement and peer heterogeneity on own achievement growth: Evidence from school transitions. Economics of Education Review, 37, 58-65.

[26] Lu, J. H., \& Jaw, G. Y. (2010). Applying MyET Oral Practice Database to Upgrade College Students' English Speaking Ability. In World Conference on E-Learning in Corporate, Government, Healthcare, and Higher Education (Vol. 2010, No. 1, pp. 1111-1115).

[27] Marsh, H. W., \& Hau, K. T. (2003). Big-fish-little-pond effect on academic self-concept: A cross-cultural (26country) test of the negative effects of academically selective schools. American Psychologist, 58(5), 364-376.

[28] Marsh, H. W., \& Martin, A. J. (2011). Academic self-concept and academic achievement: Relations and causal ordering. British Journal of Educational Psychology, 81(1), 59-77.

[29] Marsh, H. W., Byrne, B. M., \& Yeung, A. S. (1999). Causal ordering of academic self-concept and achievement: Reanalysis of a pioneering study and... Educational Psychologist, 34(3), 155-167.

[30] Marsh, H. W., Kuyper, H., Morin, A. J., Parker, P. D., \& Seaton, M. (2014). Big-fish-little-pond social comparison and local dominance effects: Integrating new statistical models, methodology, design, theory and substantive implications. Learning \& Instruction, 33, 50-66. 
[31] Marsh, H.W., Hau, K., \& Kong, C. (2002). Multilevel causal ordering of academic self-concept and achievement: influence of language of instruction (English compared with Chinese) for Hong Kong students. American Educational Research Journal, 39(3), 727-763.

[32] Marsh, H. W., Trautwein, U., Ludtke, O., Köller, O., \& Baumert, J. (2005). Academic Self-Concept, Interest, Grades, and Standardized Test Scores: Reciprocal Effects Models of Causal Ordering. Child Development, 76(2), 397-416.

[33] MyET. (2017). About L Labs. Retrieved from http://www.myet.com/MyETWeb/

[34] SubPage.aspx?fn=AboutLLabs.htm

[35] Oosterbeek, H., \& van Ewijk, R. (2014). Gender peer effects in university: Evidence from a randomized experiment. Economics of Education Review, 38, 51-63.

[36] Preckel, F., Niepel, C., Schneider, M., \& Brunner, M. (2013). Self-concept in adolescence: A longitudinal study on reciprocal effects of self-perceptions in academic and social domains. Journal Of Adolescence, 36(6), 1165-1175.

[37] Preckel, F., Zeidner, M., Goetz, T., \& Schleyer, E. J. (2008). Female 'big fish' swimming against the tide: The 'bigfish-little-pond effect'and gender-ratio in special gifted classes. Contemporary Educational Psychology, 33(1), 7896.

[38] Prince, D., \& Nurius, P. S. (2014). The role of positive academic self-concept in promoting school success. Children \& Youth Services Review, 43, 145-152.

[39] Rodriguez, C. M. (2009). The impact of academic self-concept, expectations and the choice of learning strategy on academic achievement: the case of business students. Higher Education Research \& Development, 28(5), 523-539.

[40] Schunk, D. \& Zimmerman, B. (2007). Influencing children's self-efficacy and self-regulation of reading and writing through modeling. Reading \& WritingQuarterly, 23(1), 7-25.

[41] Schwarzer, R., \& Jerusalem, M. (1989). Development of test anxiety in high school students. In I. G. Sarason \& C. D. Spielberger (Eds.), Stress and anxiety (Vol. 12, pp. 65-79). Washington, DC: Hemisphere.

[42] Suls, J. M. \& Wheeler, L. (2000). Handbook of social comparison: Theory and research. Netherlands: Kluwer Academic Publishers.

[43] Summers, A. A., \& Wolfe, B. L. (1977). Do schools make a difference? The American Economic Review, 67(4), 639-652.

[44] Sund, K. (2009). Estimating peer effects in Swedish high school using school, teacher, and student fixed effects. Economics of Education Review, 28(3), 329-336.

[45] Sung, Y., Huang, L., Tseng, F., \& Chang, K. (2014). The aspects and ability groups in which little fish perform worse than big fish: Examining the big-fish-little-pond effect in the context of school tracking. Contemporary Educational Psychology, 39(3), 220-232.

[46] Tholander, M. (2011). 'How long was your poem?' Social comparison among junior high school students. International Journal of Qualitative Studies in Education, 24(1), 31-54.

[47] Van Soom, C., \& Donche, V. (2014). Profiling First-Year Students in STEM Programs Based on Autonomous Motivation and Academic Self-Concept and Relationship with Academic Achievement. Plos One, 9(11), 1-13.

[48] Vardardottir, A. (2013). Peer effects and academic achievement: a regression discontinuity approach. Economics of Education Review, 36, 108-121.

[49] Wong, M. S. W., \& Watkins, D. (2001). Self-esteem and ability grouping: A Hong Kong investigation of the BigFish-Little-Pond-Effect. Educational Psychology, 21, 79-87.

[50] Wouters, S., Colpin, H., Van Damme, J., De Laet, S., \& Verschueren, K. (2013). Early adolescents' academic selfconcept formation: Do classmates or friends matter most? Learning \& Individual Differences, 27, $193-200$.

[51] Wouters, S., Germeijs, V., Colpin, H. \& Verschueren, K. (2011). Academic self-concept in high school: Predictors and effects on adjustment in higher education. Scandinavian Journal of Psychology, 52, 586-594.

[52] Yukselturk, E., \& Bulut, S. (2009). Gender differences in self-regulated online learning environment. Journal of Educational Technology \& Society, 12(3), 12.

[53]Zeidner, M., \& Schleyer, E. J. (1998). The big-fish-little-pond effect for academic self-concept, test anxiety, and school grades in gifted children. Contemporary Educational Psychology, 24(4), 305-329.

[54]Zimmerman, D. J. (2003). Peer effects in academic outcomes: Evidence from a natural experiment. Review of Economics and Statistics, 85(1), 9-23.

[55]Zimmerman, B. J. (2008). Investigating self-regulation and motivation: Historical background, methodological developments, and future prospects. American Educational Research Journal, 45(1), pp. 166-183.

[56]Zimmerman, B. J., \& Martinez-Pons, M. (1990). Student differences in self-regulated learning: Relating grade, sex, and giftedness to self-efficacy and strategy use. Journal of Educational Psychology, 82 (1), 51-59.

[57]Zumbrunn, S., Tadlock, J., \& Roberts, E. D. (2011). Encouraging self-regulated learning in the classroom: A review of the literature. Metropolitan Educational Research Consortium (MERC), 1-28. 